\title{
Borges's Pierre Menard and Schnitzler's Herr Huber: Language as a Topos in Fiction
}

\begin{abstract}
Can we force language to unequivocally represent reality by attaching little notes to everything and everyone around us with their names? Can we use natural languages (or develop a universal language) in such a way as to render a text perfectly stable and repeatable? These are the main questions that the protagonists raise in a novelette by Arthur Schnitzler, "Ich" (1927), and a short story by Jorge Luis Borges, "Pierre Menard: Autor del Quijote” (1939), respectively. And should these two tasks prove possible, what would that mean for translation? Would the criteria for one-to-one equivalence finally be fulfilled? In this article, which celebrates the "literary turn" in translation studies, we will look at the two aforementioned works by Schnitzler and Borges, and entertain some thought-provoking ideas on both protagonists' peculiar notions of language, as well as on their consequences for translation.
\end{abstract}

Keywords: Borges, language, Schnitzler, translation

\section{Introduction}

Arthur Schnitzler (1862-1931) and Jorge Luis Borges (1899-1986) are two of the most celebrated writers of the twentieth century, but apart from that they seem to have little in common. Nevertheless, one trait that does unite them is language as a topos in their fiction. Indeed, many of Schnitzler's later works feature language, linguistic scepticism, and the crisis of language - issues that were at the heart of the Wiener Moderne movement as a whole - as their leitmotifs. Similarly, language as a topos permeates Borges's entire oeuvre, offering a fascinating outlook on his notion of the functioning of natural languages. As a South American translation researcher who has been living in Austria for over a decade, I find the unexpected parallels between the depictions of language in their fiction striking and highly interesting - particularly in light of the fact that they most likely never read each other's work, and lived and worked in rather different settings.

In this article, we shall look at two more or less contemporary works by these authors, namely Schnitzler's 1927 novelette “Ich” and Borges's 1939 short story "Pierre Menard, Autor del Quijote," aiming to identify the notion of language that underpins the actions and reflections of their protagonists - Schnitzler's Herr Huber and Borges's Pierre Menard. Given the current trend in translation

2 Open Access. (C) 2021 Alice Leal, published by De Gruyter. (c) BY-NC-ND This work is licensed under the Creative Commons Attribution-NonCommercial-NoDerivatives 4.0 International License. 
studies of deriving insight from fiction in our discourse on language and translation (Kaindl and Spitzl 2014; Arrojo 2018), one further objective is to analyse the impact of Borges's and Schnitzler's protagonists' views on language as far as translation is concerned - an issue more obviously related to Borges's short story, but still pertinent in relation to Schnitzler's novelette. This trend in translation studies, known as the "fictional turn," puts fictional works, too, as opposed to solely academic texts, in the spotlight as legitimate sources of insight into language and translation, and represents "one of the main contributions to translation theory" at the turn of the present century (Pagano 2002, 81).

Assuming that most readers are familiar either with Borges or with Schnitzler, but not with both, I will provide a relatively detailed summary of key points in their biographies and literary work (sections 2.1 and 3.1), which will be followed by an analysis of Herr Huber's (section 2.2) and Pierre Menard's (section 3.2) notions of language based on the aforementioned stories. Finally, we shall see how these characters' thoughts on language can be relevant to translation (section 4). The article will end with a few closing remarks (section 5).

\section{Arthur Schnitzler's Herr Huber}

\subsection{Arthur Schnitzler and the Wiener Moderne}

Arthur Schnitzler (1862-1931) is one of the "most prominent and most controversial [Austrian] writer[s]" of all times (Gay 2002, xxviii). He wrote two novels and around forty plays, as well as sixty short stories and novellas; over a dozen of his works have been adapted to the cinema, the most renowned example of which is Stanley Kubrik's 1999 Eyes Wide Shut. Schnitzler's biography and literary path illustrate the life of the bourgeoisie in Central Europe at the fin de siècle (Lorenz 2003, 1; Gay 2002, xix-xxii).

Before we analyse Schnitzler's biography, however, let us take a quick look at the Wiener Moderne, the group of artists and intellectuals that took Vienna - and the world - by storm at the turn of the century. For Carl E. Schorske, the so-called Vienna schools "produced innovations" initially in psychology, music, and art history, and later in literature, architecture, plastic arts, and political science (1981, x-xvi). Gotthart Wunberg, in his anthology entitled Die Wiener Moderne (1981), includes, among many others, works by or about Arthur Schnitzler, Hugo von Hofmannsthal, Robert Musil, Sigmund Freud, Ernst Mach, Hermann Bahr, Karl Kraus, Richard Beer-Hoffmann, Peter Altenberg, Gustav Klimt, Otto Wagner, Gustav Mahler, and Arnold Schönberg. 
What united such different names in a single group? As Schorske (1981, xvixvii) explains, it was a combination of several factors, including Austria's unique socio-historical and cultural context at the end of nineteenth century, due, on the one hand, to the astounding "temporal compression" (1981, xvi) with which modernism settled and quickly ripened in the country and, on the other hand, to the late ascension and rapidly following crisis of the liberal middle class. Additionally, two factors played a pivotal role in the formation of the Wiener Moderne. (i) In Austria, unlike in its European neighbours, the circles in question gathered at the same Viennese cafés and sat side-by-side with other increasingly prestigious social, professional, and intellectual groups, which in turn made the Austrian elite at the time relatively cohesive; and (ii) these groups embodied an unparalleled combination of provincialism and cosmopolitanism, traditionalism and modernism (Schorske 1981, xvii; Wunberg 1981, 637; Gay 2002, 23). This set of factors made up the melting pot of the Wiener Moderne, a group of révoltés whose common enemy were the values inherited from classic liberalism (Leal 2017, 315).

Within the Wiener Moderne there was a group known as Jung-Wien (also spelled Junges Wien or Jungwien), a significantly smaller circle of writers - essayists, playwrights, poets, and novelists. Its main members and leaders are relatively indisputable: Hugo von Hofmannsthal, Arthur Schnitzler, and Hermann Bahr (Rider 1990, 15). Wunberg $(1981,18)$ adds Leopold von Andrian-Werburg, Richard Beer-Hofmann, Ferdinand von Baumgartner, Felix Salten, Richard Specht, Leo Feld, Felix Dörmann, Ferry Bération, Karl Kraus, and Peter Altenberg to the list, whereas Patricia Ann Andres (2008, 44) also mentions Stefan Zweig, Siegfried Trebitsch, Jakob Wasserman, Paul Wertheimer, Theodor Herzl, and Raoul Auernheimer, among others. The maxim that united the group's literary programme was "die Wahrheit, wie jeder sie empfindet" [the truth according to one's perception], ${ }^{1}$ which entailed the anti-essentialist shift from the object "itself" to the perception (inescapably subjective) of the object (Wunberg 1981, 33). As Jacques Le Rider $(1990,16)$ explains, this (at the time) innovative anti-essentialist gesture was linked with the desire, in Austria, to overcome German naturalism. Moreover, it was also intimately related to one of the main leitmotifs of the group, namely the crisis of the self. In his famous essay "Das unrettbare Ich," for instance, Hermann Bahr argues that the self cannot be rescued - neither by the gods nor by the earth, since both have been dethroned by reason. What matters is hence not the truth but rather the illusions of whatever we need in order for life to move on (Bach 2010, 47). No wonder Nietzsche was one of the greatest influences on the group (Wunberg 1981, 133).

1 All translations in this article are my own unless otherwise noted. 
Another topos that permeated the group's works and is at the forefront of the work analysed in this article is linguistic scepticism. The same crisis that afflicted the self also afflicted language in the following terms, formulated by Cecil A. M. Noble: “die wachsende Erkenntnis, daß Wort und Wirklichkeit einander nicht mehr decken, daß die traditionelle Sprache nicht mehr kongruent ist mit neuen Erfahrungszusammenhängen” [the growing knowledge that words don't represent reality, that traditional language is at odds with new experiential contexts] $(1978,7)$. And even though this subject had always been present as a theme in world literature, it was not until the mid-nineteenth and early twentieth century that it became an insurmountable obstacle in literature (Noble 1978, 19-20) and in philosophy (Kacianka and Zima 2004, 7; Leal 2014, 99). We shall look at examples of linguistic scepticism in section 2.2 below.

Arthur Schnitzler, one of the most renowned members of both groups, was born in 1861, the firstborn in a relatively well-off Jewish family in Vienna. His father was a successful doctor and expected his son to follow in his footsteps, which he did, but only half-heartedly. At the age of eighteen, Arthur had already written twenty-three plays, along with first drafts for another thirteen (Wisely 2004, 4-5). It was not until his father's death in 1893, however, that the young doctor gradually scaled down and eventually quit his job in his father's polyclinic to make writing his full-time job (Lorenz 2003, 1-2; Wisely 2004, 8). That same year witnessed Schnitzler's establishment as a celebrated playwright in the German-speaking word, thanks chiefly to the publication of the full set of the Anatol plays in Berlin (Lorenz 2003, 2-3).

Schnitzler's marriage to Olga Gussman in 1903 and subsequent divorce in 1921 - a relationship that gave them two children, Heinrich (1902) and Lili (1909) is not usually at the forefront of his various biographies. Instead, his biographers focus on his countless affairs, and, indeed, Schnitzler's diaries decidedly confirm his reputation as a playboy and bon vivant. His daughter's suicide in 1928, three years prior to Schnitzler's own death as a result of a stroke, is also very much commented on, as father and daughter were extremely close. The sombre character of the author's last few years of life is often attributed to her death (Lorenz 2003; Wisely 2004), a fact that his diaries also confirm (Farese 2010; Leal 2017, 319).

Another aspect of his life which is often scrutinized by his critics and biographers is his ambivalent relationship with Sigmund Freud, his colleague at medical school and then (in Freud's words) doppelgänger in later years (Wunberg 1981, 651-653). Though they never established close ties, they were both in the spotlight of Viennese society and knew each other's works very well. It is well known, for instance, that Schnitzler started writing down his dreams after reading Freud's Traumdeutung (Farese 2010, 34), and that Freud avoided Schnitzler because the latter writer seemed to understand the principles of psychoanalysis purely by 
instinct, whereas Freud needed to resort to numerous clinical cases (Freytag 2007, 10; Loentz 2003, 79). Both enjoyed a lot of success at home and abroad until the 1930s and the rise of the National Socialist Party. The 1950s saw very few productions of Schnitzler's plays at all, and the connections between his works and Freud's psychoanalysis only made critics more impatient (Deutsch-Schreiner 2003, 59-60). It was not until the 1960s that Schnitzler's works experienced a comeback in his homeland, and it was not until the 1980s that he was granted the status of a modern European writer (Deutsch-Schreiner 2003, 72).

\subsection{Herr Huber and his notion of language}

Schnitzler's novelette "Ich" is considered a fragment by critics, as it was written in 1927 and then published posthumously. For Michael Scheffel (2006, 392-393), the story is a parody of Hugo von Hofmannsthal's 1902 "Brief des Lord Chandos an Francis Bacon" (Hofmannsthal 1980), in which the protagonist, Lord Chandos, announces his outright renunciation of his literary practice to Francis Bacon, blaming it on the alleged decay of language (Leal 2014, 103).

Schnitzler's novelette is narrated in the third person in free indirect style, and is set in Vienna. Although the exact time is not mentioned (nor is it relevant), there are minor indications that the story takes place at the turn of the century. Its protagonist, Herr Huber, is initially depicted as a perfectly normal middle-aged man, giving the story an almost dull atmosphere initially, which the word-choices in the first paragraph of the story confirm: "normal," "silently," "playfully," “innocuous," “cheerful," “quiet," “good," "simple,” "good-mannered,” "beautiful," "little trivial incidents" (Schnitzler 2006, 304). The first line of the story, however, foreshadows the epiphany that is about to take place and completely change the atmosphere - initially monotonous - of the novelette: "To this day he had always been a completely normal man" (304). In the fourth paragraph, the reader is pulled back to the present time of the narrative ("tonight"; 305), a break that announces the imminent change.

Whilst taking one of his customary strolls through the hills at the western end of Vienna, Huber notices an old-looking wooden sign with the word "Park" written on it and begins to wonder whether such an obvious indication is necessary: "But of course this was a park, the Schwarzenberg Park, there was no doubt about it whatsoever [...]. Anyone could see it was a park, there was no doubt about it whatsoever" (Schnitzler 2006, 306). He starts wondering about the relationship between language and reality, and whether there may be people who, faced with the same reality, arrive at different words or have different perceptions of this reality. From this point onwards, the narrator's voice becomes increasingly entan- 
gled with the protagonist's voice, with bursts of stream of consciousness here and there. Herr Huber gradually comes to the conclusion that the park sign might not be pointless after all: "Very prudent, actually, to have that sign hanging on that tree saying 'Park.' Not everyone was as quick-witted and perspicacious as he was, to be able to tell automatically that this is a park, and this is a necktie" (308). Slowly, the sign comes to seem indispensable after all, since there may be people who do not have the same presence of mind as he, for example, does - "What a relief to know that, out there, there was a sign with the word 'Park' written on it" (310).

This epiphany changes the atmosphere of the novelette drastically - the vast, open spaces of the previous paragraphs are replaced with more confined places, in which Herr Huber is unable to escape his now-pressing reflections. His only source of relief is to attach little notes to objects and people around him with their names, to which Herr Huber's wife reacts with puzzlement. His explanation is that "it was a joke. [...] But it is important to teach the little ones the names of things and people as early as possible. What a tremendous confusion in the world. No one knows anything" (Schnitzler 2006, 310). And though his wife removes all the notes he has placed in the house, Herr Huber puts them up again, as a means of obtaining some sense of stability and relief. Frau Huber, ultimately assuming her husband is sick, calls the doctor, upon whose arrival Herr Huber is wearing a sign on his own chest on which the word "Me" is written in large letters (311; see Leal 2014, 105-106). And so, on this tragicomic note, the novelette ends abruptly, as though the narrator were trying to highlight the impossibility and the insanity of Herr Huber's endeavour.

But let us focus here on Herr Huber's voice instead of on the narrator's: by writing words down, Herr Huber attempts to stabilize language, to free it from possible misunderstandings, ambivalent meanings, misinterpretations. His gesture unlike Lord Chandos's gesture of utter renunciation - is filled with hope for a less chaotic means of communication (if we ignore his naivety for a moment - what did he intend to do, for example, with abstract nouns, verbs, or prepositions?). His gesture is underpinned by a well-known and age-old wish - particularly in philosophy of language, but also in translation studies - to tame language, to rid it of its elusive character once and for all. Plato already spoke of this with great concern: "present language seems to be a corruption of an original fidelity to nature. [...] Names have been so twisted that the original language might appear to be a barbarous tongue to present speakers" $(1921,397)$.

There have been numerous attempts in philosophy of language to solve this "problem," as we will see in section 4 below. Yet is the inevitable potential of natural languages to generate misunderstandings necessarily a problem at all? Lord Chandos and Herr Huber certainly think so. Let us look at another char- 
acter's perspective, that of Borges's Pierre Menard, before we come back to this question in section 4.

\section{Borges's Pierre Menard}

\subsection{Jorge Luis Borges}

The internationally acclaimed writer Jorge Luis Borges was born in Argentina in 1899 "under a curse," as Tim McNeese puts it $(2008,6)$, referring to the blindness and poor eyesight that plagued the Borges family. His parents soon realized that their son was not going to be spared. Jorge's father was himself almost blind at the age of forty, when he and his family - Jorge was fifteen then, and his sister Norah, later a "well-regarded painter," was thirteen - moved to Geneva to seek treatment (Burgin 1998, xiii; see also McNeese 2008, 10, 17). However, even before they moved abroad, Borges's family was relatively international, with both English and Spanish being spoken at home - the former thanks to his grandmother, who was from Northumbria in England (McNeese 2008, 14). Being a multilingual intellectual himself, Borges's father had a quite extraordinary library, with most of the collection made up of English classics (McNeese 2008, 15). In Switzerland, Borges learned French and Latin at school, and also learned German by himself (Burgin 1998, xiii). So, in addition to English-language classics, he also became an avid reader of Heine, Nietzsche, Schopenhauer, and the French symbolists (Burgin 1998, xiii). Borges's family would stay in Geneva for four years and then spend another two in Madrid before moving back to Buenos Aires, by which time he had already produced a few literary works, namely the story "La visera fatal," borrowed from Don Quijote, at the age of seven; a Spanish translation of Oscar Wilde's The Happy Prince, at the age of nine; his first published short story, "El Rey de la Selva," at thirteen; and his first poem, "Himno al mar," which was published in Spain, at twenty (Burgin 1998, xiii).

In 1921, back in Argentina, Borges launched the magazine Prism, and a year later, together with friends, the magazine Proa. In 1923, his first collection of poems, Fervor de Buenos Aires, was published. What followed was an interminable list of collections of poems, essays, edited volumes, short stories, detective stories, translations, scholarly works, and lectures (Burgin 1998, xiv-xx; McNeese 2008, 106-109). From 1937 to 1948, he worked at a municipal library in Buenos Aires, before resigning the post as a poultry inspector to which he had just been appointed in a move by the Perón regime to punish him for protesting against it. Two years later, his mother and sister would serve time in prison for demon- 
strating against the regime as well (Burgin 1998, xv-xvi). This pushed Borges into academia: he first became a lecturer and then, in 1950, a professor of English and American literature at the Argentine Association of English Culture (Burgin 1998, $\mathrm{xvi}$ ). In the following decades, he received both numerous honorary doctorates from the University of Cuyo, Argentina, in 1956; Columbia University and the University of Oxford, both in 1971; the Sorbonne in 1977; Harvard in 1981; and many others - and literary prizes such as the Argentine National Prize for Literature in 1957, the Formentor International Publishers' Prize (with Samuel Beckett) in 1961, the Literary Prize of the Ingram Merrill Foundation in 1965, and the Cervantes Prize in 1980 (Burgin 1998, xvi-xx; McNeese 2008, 106-109).

Borges was appointed director of the National Library in Argentina by the military regime that overthrew Perón, a post he kept until 1973, when Perón, by then in his third mandate, allowed his retirement (Burgin 1998, xvii, xix). However, both during this period and later on, he continued acting as professor at various universities all over the world - including the Faculty of Philosophy and Letters in Buenos Aires, the University of Texas, the Stella Maris Catholic University of Argentina, and Harvard (Burgin 1998, xvii-xx). The first English translations of his work (Fictions and Labyrinths) appeared in book form in 1962, and the next few decades witnessed the publication of a long list of translations and critical works on his oeuvre (Burgin 1998, xvii-xx). Many of his stories were adapted to the cinema in Argentina, Italy, the US, and France, and several films and plays based on his life and works were produced in different countries (Burgin 1998, xvii-xx; McNeese 2008, 106-109).

As early as the 1930s, the "curse" of poor eyesight mentioned earlier started taking a toll on Borges - in 1938, he was involved in a car accident as a result and almost lost his life. According to the critics, he wrote "Pierre Menard: Autor del Quijote" while convalescing, to test his sanity (Burgin 1998, xv; Wilson 2006, 107). Having "fallen into near blindness," Borges relied heavily on family members (most notably his mother), as well as friends and companions - the vast majority of whom were male - to read to him, to dictate his works to, and so on (McNeese 2008, 84). Into middle age and in his later years, Borges started surrounding himself with - usually much younger - female companions/secretaries as well, and he did become involved with some of them (McNeese 2008, 84-85). He remained single until 1967, when he married his childhood sweetheart and now secretary Elsa Astete Millán, whom he divorced less than three years later (Burgin 1998, xviii; Wilson 2006, 137). A few months before his death in 1986 as a result of liver cancer, he married his personal assistant, María Kodama (Burgin 1998, xx; McNeese 2008, 109). 


\section{2 "Pierre Menard: Autor del Quijote" and his notion of language}

This is known as Borges's “first truly 'Borgesian' tale” (McNeese 2008, 108), written at a pivotal moment in his life (see 3.1). In an interview with Richard Burgin in 1967, Borges explained that the story is about the fact that "every time a book is read or reread, then something happens to the book. [...] it's really a new experience” (Burgin 1998, 15-16). Pierre Menard is a fictitious Frenchman of letters - although according to Wilson $(2006,107)$, the idea was inspired by Gustave Lanson's 1923 history of French literature, in which a certain "Louis Menard" is mentioned once in a footnote. For Wilson, the tale is a self-portrait of Borges in the crisis that followed his near-death experience: "Borges saw himself as a footnote in world literature” (Wilson 2006, 107).

Borges' short story is a “hoax review” (Wilson 2006, 107) of Menard's works at first glance, little indicates that it is fiction and not a real review. The story opens with a first-person narrator cataloguing Pierre Menard's "visible works," which include (in Andrew Hurley's translation) a relatively long list of monographs and articles on Descartes, Leibniz, John Wilkins, Ramon Lull, and George Boole, along with texts on the game of chess, on French poetry, as well as Menard's own poetry and poetic translations (Borges 1998, 89-90). The list is furnished with sources and explanatory footnotes; the style is academic throughout and includes quotations. We are informed at the end of the "review," just as is customarily done, when and where the text was written: "Nîmes 1939" (95). The narrator takes it for granted that the readers know who Menard is - he is referred to as "this novelist" and "the mourned-for poet," for example $(1998,88)$. Were it not for the series of humorous, ironic remarks, such as the one in the first footnote about Menard's “literal translation of Quevedo's literal translation of St. Francis de Sales's Introduction à la vie dévote" (90), we might actually believe that we are faced with a genuine - though old-fashioned, perhaps in accordance with the dominant style in the 1930s - review of a famous writer's oeuvre.

The narrator goes on to explain that what truly matters, nevertheless, is not Menard's visible work, but rather "the other, the subterranean, the interminably heroic production [...] perhaps the most significant writing of our time” (Borges 1998, 90), namely a few chapters and fragments of Miguel de Cervantes's Don Quijote. Not a translation, not an adaptation, not a rewriting, not a copy: "Pierre Menard did not want to compose another Quixote, which surely is easy enough he wanted to compose the Quixote" (91; emphasis in original), albeit three centuries later. In order to do so, he first considered a "relatively simple" method: "Learn Spanish, return to Catholicism, fight against the Moor or Turk, forget the history of Europe from 1602 to 1918 - be Miguel de Cervantes" (91; emphasis in original). 
Menard then quickly dismissed this initial idea as "too easy" (91). At this point, the narrator warns us, in one of his typical interactions with the readers, "Too impossible rather!, the reader will say. Quite so, but the undertaking was impossible from the outset" (91). We had been informed earlier that this work, however significant, was invisible, unfinished. Now we know that it is also impossible. A little further, the narrator inserts a long quotation from Menard himself, in which the latter asserts that "composing the Quixote in the early seventeenth century was a reasonable, necessary, perhaps even inevitable undertaking; in the early twentieth, it is virtually impossible. Not for nothing have three hundred years elapsed, freighted with the most complex events. Among those events, to mention but one, is the Quixote itself” (Borges 1998, 93). Yet the enthusiasm and awe with which the narrator tells us about it fills us with curiosity. How did Menard intend to complete this impossible task? And if it was impossible from the outset, why insist on it?

Menard finally opted not to turn into Miguel de Cervantes, but rather to remain Pierre Menard and to arrive at "the Quixote through the experiences of Pierre Menard" (Borges 1998, 91; emphasis in original). The narrator then quotes Menard's words on his undertaking, saying it "is not in essence difficult. [...] If I could just be immortal, I could do it” (91-92). What follows in the short story is a detailed analysis of Menard's work on Quixote, including comments by other critics and comparisons between Cervantes's and Menard's texts. The narrator concludes that "the Cervantes text and the Menard text are verbally identical, but the second is almost infinitely richer" and "the contrast in styles is equally striking” (94), for Menard's style sounds archaic and foreign, whereas Cervantes "employs the Spanish of his time with complete naturalness" (94).

Two closing remarks by the narrator take us back to Borges's analysis of his own story, which was mentioned earlier in this section: "There is no intellectual exercise that is not ultimately pointless" and, especially, "it is legitimate to see the 'final' Quixote as a kind of palimpsest, in which the traces [...] of our friend's 'previous' text must shine through" (Borges 1998, 94-95). In other words, every text becomes a new text once it is read and reread, a realization to which our narrator, and perhaps Menard himself, seems to come. Menard failed at his most sublime undertaking because, despite producing a "verbally identical" (94) text to Cervantes's, they were still different, not least because they were written by two completely different people three centuries apart. The "same" words are read differently, have a different impact when attributed to Cervantes in the seventeenth century as opposed to Menard in the twentieth. Indeed, the short story ends on this very note: "Attributing the Imitatio Christi to Louis Ferdinand Céline or James Joyce - is that not sufficient renovation of those faint spiritual admonitions?" (95).

Pierre Menard's insistence on his impossible undertaking, along with his keen interest particularly in Leibniz, but also in Descartes, Wilkins, Lull, and Boole, is 
underpinned by a wish similar to that of Schnitzler's Herr Huber, namely to free language of its elusive character, to stabilize language and to use it in a purely logical, unequivocal, and hence perfectly repeatable fashion. All these philosophers attempted as much: to remedy the flaws of natural languages by resorting to elaborate classification systems and/or universal languages. Menard's ultimate failure is nothing more than the failure of this very project (see Leal 2018).

Hofmannsthal's Lord Chandos loses faith in language and feels overwhelmed by its fragmentary character. Both Herr Huber and Pierre Menard, on the other hand, believe that, despite (or because of) the chaos inherent to human languages, they must be proactive and take measures to "control" language and achieve linguistic stability. Thus Pierre Menard sets out to "rewrite" Don Quijote in Spanish, whereas Herr Huber embarks on a quest to name all the objects and people around him by attaching little notes to them (Leal 2014, 106). One could argue that the narrators in both stories make the absurdity of their protagonists' quests evident, revealing an attitude towards language that is perhaps different from those of Menard and Huber themselves. And this point takes us to the fertile discussion, in literary studies, surrounding the distinction between narrators' and authors' voices - to what extent could we claim that Borges's narrator and Schnitzler's narrator echo their own authors' voices? But let us focus here, due to space constraints, on Pierre Menard's and Herr Huber's views on language and their impact on translation, which will be detailed in the next section. ${ }^{2}$

\section{Language and translation}

According to George Steiner (1998, 76-77), most theories of language are marked either by a predominantly universalist or relativist matrix. The former "declares that the underlying structure of language is universal and common to all men," whereas the latter "holds that universal deep structures are either fathomless to logical and psychological investigation or of an order so abstract, so generalized as to be well-nigh trivial." These matrices - though radically opposed - should not be perceived as mutually exclusive, since most theories of language will present traces, however subtle, of both simultaneously.

Universalist theories can be traced back to Heraclitus, Parmenides, and most notably Plato. For them, language is logos, that is, the place where word

2 For more on the different "types of narration" and "the author's voice in fiction," see Booth (1982, 149-242), as well as Compagnon (2004, 29-68). 
and reality represent each other univocally. Speech is the direct representation of thought; the former is hence secondary, derivative of the latter. Therefore, in the classical paradigm, the function of language is reduced to one of reference, of representing reality (Braun 1996, 5-8; Hoffmann 2003, 27; Leal 2018, 226-228). These universalist seeds - in other words, the firm belief in or yearning for a language that represents reality directly, logically, and objectively - have given rise to widely different theories of language over the past millennia, from Leibniz's characteristica universalis and scientia generalis, Böhme and Hamann's notion of divine logos, Frege's third realm, Russell's and the early Wittgenstein's firm belief in the referential character of language, and Carnap's ideal language philosophy, to Habermas's universal conditions for mutual understanding, Chomsky's universal grammar, and various aspects of Saussure's structuralism (Leal 2018, 231-243). Descartes's, Wilkins's, Lull's, and Boole's theories of language could be added to this list, as already mentioned in the previous section.

Both Herr Huber and Pierre Menard share this notion of language as a means of representing reality unequivocally - or at least the wish that it did so. Herr Huber reveals this belief or wish by labelling everything and everyone around him, hoping that written words will bind language to reality definitively, thus riding language of obscurity and ambiguity. Pierre Menard reveals his belief in a similar notion of language by stubbornly and relentlessly trying to "repeat" a three-hundred year-old text, clinging to words as though they were stable receptacles of unchanging meaning. Unlike Herr Huber, nonetheless, who persists on his quest, Pierre Menard eventually comes to terms with the impossibility of his an awareness of which he probably had from the outset, as we have seen above.

Any progress in these predominantly universalist theories of language would entail either an unprecedented systematization of natural languages or the development of an all-embracing universal language. Either way, for translation studies this would mean the lost link, the piece of the puzzle required to establish perfect equivalence between languages and thus turn translation into an objective, logical, and perhaps even automatic task - and the recent developments in machine translation point in this direction. It is as Paul Ricoeur suggests: in order to criticize a translation effectively, we would have to compare source and target texts to a third text, "the bearer of the identical meaning, supposed to move from the first to the second" (2006, 34). Nevertheless, no theory of language has ever managed to locate or (re)create this "third place," and therein lies the "paradox" of translation, according to Ricoeur, since equivalence is always and only "supposed equivalence" because there is no "demonstrable identity of meaning" (2006, 22).

However, would progress in this direction be a blessing or a curse for those of us who work with language - be it in literary studies, linguistics, translation 
studies, or philosophy of language, for instance? And how realistic are the expectations that one day a theory of language or a universal language will emerge and revolutionize the way that we communicate? Let us look into these two final questions in the next section.

\section{Final remarks}

Schnitzler's “Ich” and Borges’s "Pierre Menard: Autor del Quijote” offer precious insights into how one can understand language. Their protagonists' views are deeply rooted in philosophy of language, particularly in those theories labelled "universalist” by Steiner, as mentioned above - which arguably unveils Borges's and Schnitzler's more relativist convictions. However, Steiner stresses that the quest for "unambiguous and universal codes of communication" $(1998,208)$ has achieved very little, adding that "the logician is out of sorts from the start" because language has little to do with logic (225). For him, "the directly informative content of natural speech is small," so we speak about what is not, what might be, and so on, and this is one of our "greatest [...] tools by far" $(231,234)$. The "looseness" of natural languages is an evolutional advantage in his view, "crucial to the creative functions of internalized and outward speech," so that "new worlds are born between the lines" $(238,239)$. Therefore, the elusive character of language need not be seen as a hindrance to the development of objective notions like equivalence and identity of meaning, but rather as the very reason why there are so many languages in the first place and why translation is possible. Seen from this perspective, significant progress in universalist theories would be neither realistic nor desirable.

Indeed, if we take the other matrix to which Steiner refers, namely the relativist matrix, it becomes clear that this "looseness" of natural languages - which is responsible for Herr Huber's and Menard's ultimate failure - can and should be celebrated. Predominantly relativist theories can be traced back to nominalism, with, among others, Hobbes, Bacon, Locke, and later Hume at its forefront. For Jacques Derrida, nevertheless, it is not until contemporary thought and post-structuralism that the first non-logocentric notions of language emerge, that is, the first notions of language completely detached from the logos, from the possibility of or wish for an identity of meaning outside language. 


\section{Works cited}

Andres, Patricia Ann. "Erzählen heißt, der Wahrheit verschworen sein": Kommentierte Edition der deutsch- und englischsprachigen Fassung des bisher unveröffentlichten KZ-Berichts Die Zeit im Lager - Through Work to Freedom von Raoul Auernheimer. Frankfurt am Main: Lang, 2008.

Arrojo, Rosemary. Fictional Translators: Rethinking Translation through Literature. London and New York: Routledge, 2018.

Bach, Hermann. Studien zur Kritik der Moderne. Weimar: Verlag und Datenbank für Geisteswissenschaft, 2010.

Booth, Wayne C. The Rhetoric of Fiction. 1961. 2nd ed. Chicago: University of Chicago Press, 1982.

Borges, Jorge Luis. “Pierre Menard: Author of the Quixote." Collected Fictions: Jorge Luis Borges. By Borges. Trans. Andrew Hurley. New York: Penguin, 1998. 88-95.

Braun, Edmund. Der Paradigmenwechsel in der Sprachphilosophie. Darmstadt: Wissenschaftliche Buchgesellschaft, 1996.

Burgin, Richard. Jorge Luis Borges: Conversations. Jackson: University Press of Mississippi, 1998.

Compagnon, Antoine. Literature, Theory, and Common Sense. Trans. Carol Cosman. New Jersey: Princeton University Press, 2004.

Deutsch-Schreiner, Evelyn. ““... nothing against Arthur Schnitzler himself ...': Interpreting Schnitzler on Stage in Austria in the 1950s and 1960s." A Companion to the Works of Arthur Schnitzler. Ed. Dagmar C. G. Lorenz. New York: Camden House, 2003. 59-78.

Farese, Giuseppe. “Arthur Schnitzlers Tagebücher und Briefe: Alltag und Geschichte.” Schnitzler's Hidden Manuscripts. Eds. Lorenzo Bellettini and Peter Hutchinson. Berne: Lang, 2010. 23-48.

Freytag, Julia. Verhüllte Schaulust: Die Maske in Schnitzlers "Traumnovelle" und in Kubricks “Eyes Wide Shut." Bielefeld: transcript Verlag, 2007.

Gay, Peter. Schnitzler's Century: The Making of Middle-Class Culture 1815-1914. New York: Norton, 2002.

Hoffmann, David. “Logos as Composition.” Rhetoric Society Quarterly 33.3 (2003): 27-53.

Hofmannsthal, Hugo von. "Ein Brief.” Die Wiener Moderne: Literatur, Kunst und Musik zwischen 1890 und 1910. Ed. Gotthart Wunberg. Stuttgart: Reclam, 1980. 431-444.

Kacianka, Reinhard, and Peter V. Zima. Krise und Kritik der Sprache: Literatur zwischen Postmoderne und Spätmoderne. Tübingen: Francke, 2004.

Kaindl, Klaus, and Karlheinz Spitzl. Transfiction: Research into the Realities of Translation Fiction. Amsterdam: John Benjamins, 2014.

Leal, Alice. "Linguistic Scepticism and the Jung-Wien: Towards a New Perspective in Translation Studies." trans-kom 7.1 (2014): 99-114.

Leal, Alice. “Arthur Schnitzler e a Linguagem na Ficção." Revista Versalete 5.8 (2017): 312-332.

Leal, Alice. "Equivalence." The Routledge Handbook of Philosophy and Translation. Eds. Piers Rawling and Philip Wilson. London and New York: Routledge, 2018. 224-242.

Loentz, Elizabeth. "The Problem and Challenge of Jewishness in the City of Schnitzler and Anna 0." A Companion to the Works of Arthur Schnitzler. Ed. Dagmar C. G. Lorenz. New York: Camden House, 2003. 79-102.

Lorenz, Dagmar C. G. "Introduction.” A Companion to the Works of Arthur Schnitzler. Ed. Lorenz. New York: Camden House, 2003. 1-24. 
McNeese, Tim. Jorge Luis Borges. New York: Chelsea House Publishers, 2008.

Noble, Cecil A. M. Sprachskepsis: Über Dichtung der Moderne. Munich: Edition text + kritik, 1978.

Pagano, Adriana S. "Translation as Testimony: On Official Histories and Subversive Pedagogies in Cortázar.” Translation and Power. Eds. Maria Tymoczko and Edwin Gentzler. Amherst: University of Massachusetts Press, 2002. 80-98.

Plato. Cratylus. Plato in Twelve Volumes. Trans. Harold N. Fowler. Vol. 12. Cambridge: Harvard University Press; London: Heinemann, 1921. 383-440.

Ricoeur, Paul. On Translation. Trans. Eileen Brennan. London and New York: Routledge, 2006. Rider, Jaques Le. Das Ende der Illusion. Vienna: ÖBV, 1990.

Scheffel, Michael. “Nachwort.” Arthur Schnitzler: Traumnovelle und andere Erzählungen. By Arthur Schnitzler. Ed. Scheffel. Frankfurt am Main: Fischer, 2006. 385-394.

Schnitzler, Arthur. Traumnovelle und andere Erzählungen. Frankfurt am Main: Fischer, 2006. Schorske, Carl E. Fin-de-Siècle Vienna: Politics and Culture. New York: Vintage, 1981.

Steiner, George. After Babel: Aspects of Language and Translation. London: Oxford University Press, 1998.

Wilson, Jason. Jorge Luis Borges. London: Reaktion Books, 2006.

Wisely, Andrew C. Arthur Schnitzler and Twentieth-Century Criticism. New York: Camden House, 2004.

Wunberg, Gotthart. Die Wiener Moderne: Literatur, Kunst und Musik zwischen 1890 und 1910. Stuttgart: Reclam, 1981.

Alice Leal is senior lecturer in Translation Studies at the University of Vienna, Austria. Her first book, on translation studies in Brazil, was published by Frank \& Timme in 2014. Her recent publications include chapters in the Routledge Encyclopedia of Translation Studies, the Routledge Handbook of Translation and Globalization and the Routledge Handbook of Translation and Philosophy, along with articles in different translation studies journals. Her second book, English and Translation in the European Union after Brexit, is due to come out in 2021 (Routledge). Her main areas of research are translation theory, philosophy of language, multilingualism, and post-structuralist discourse. 
